\title{
Local foods and low-income communities: Location, transportation, and values
}

\author{
James R. Farmer ${ }^{a *}$ and Sara Minard ${ }^{b}$ \\ Indiana University \\ Cliff Edens ${ }^{c}$ \\ Monroe County United Ministries
}

Submitted November 4, 2015 / Revised March 14, April 11, and April 26, 2016 / Accepted

April 29, 2016 / Published online September 19, 2016

Citation: Farmer, J. R., Minard, S., \& Edens, C. (2016). Local foods and low-income communities:

Location, transportation, and values. Journal of Agriculture, Food Systems, and Community Development,

6(4), 41-53. http://dx.doi.org/10.5304/jafscd.2016.064.009

Copyright (C) 2016 by New Leaf Associates, Inc.

\begin{abstract}
While many state and federal programs exist to combat food insecurity, local-level community initiatives are also working to increase public access to local and healthy foods. Nevertheless, a prime venue for distributing local and healthy foodsfarmers markets - primarily serve white, middleand upper-class consumers. In an attempt to better
\end{abstract}

a * Corresponding author: James R. Farmer, Ph.D., Assistant Professor, Department of Recreation, Park, and Tourism Studies, School of Public Health-Bloomington; Ostrom Workshop in Political Theory and Policy Analysis, Indiana University; 1025 East $7^{\text {th }}$ Street; Bloomington, Indiana 47405 USA; +1-812-856-0969; jafarmer@indiana.edu

b Sara Minard, M.S., Visiting Lecturer, Department of Geography, Indiana University; Student Building; Bloomington, Indiana 47405 USA.

${ }^{c}$ Cliff Edens, Emergency Services Coordinator, Monroe County United Ministries; 827 West $14^{\text {th }}$ Street; Bloomington, Indiana 47404 USA. understand the barriers and facilitators affecting consumer participation in farmers markets, we use the case of participation in a community farmers market in Bloomington, Indiana. Drawing on survey data collected from two neighborhood groupings near the farmers market-one mixedincome and one low-income-we explore behavioral facilitator and constraint concepts associated with food values and farmers market shopping decisions. Building on previous scholarship on the dynamics of farmers market participation, our results indicate that perceptions of quality/freshness, and ease/difficulty of transportation to acquire food, are key factors for

\section{Disclosure}

This project was supported by the Indiana Clinical and Translational Sciences Institute, funded in part by grant \#UL1 TR001108 from the National Institutes of Health, National Center for Advancing Translational Sciences, Clinical and Translational Sciences Award. 
both the low- and mixed-income individuals. As such, we suggest that local food advocates can best serve low- and mixed-income communities by promoting ongoing community health education efforts that emphasize the importance of fresh, healthy foods, and by facilitating the positioning of small-scale farmers markets in close proximity to such neighborhoods or bringing fresh produce to underserved neighborhoods through the use of mobile markets.

\section{Keywords}

Local Food Systems; Farmers Markets; Food Security

\section{Introduction}

Consumers in the United States are increasingly demanding alternatives to conventionally produced food, as evidenced by the growth of the local food movement and of direct agricultural markets that allow consumers to purchase locally grown, fresh foods directly from producers (Martinez et al., 2010). Some common forms that these direct-toconsumer markets take include roadside fruit and vegetable stands, community-supported agriculture programs, and farmers markets. Notable among these are farmers markets, which grew in number by $450 \%$ between 1994 and 2012 (U.S. Department of Agriculture, Agricultural Marketing Service [USDA AMS], 2016). Farmers markets and other direct-to-consumer retail outlets are commonplace in the discussion of local food systems, as they promote the re-localization of food and agriculture in opposition to the current industrial agriculture system dominated by large multinational corporations (Farmer, Chancellor, Gooding, Shubowitz, \& Bryant, 2011; Hinrichs, 2003; Lyson, 2004).

Community activists have embraced localized food systems as a multifunctional approach to increasing the sustainability of food systems and improving health outcomes for local populations. Developing alternative systems of food distribution works to tighten the gap between food producers and consumers at local and regional scales (Dahlberg, 1993). By shortening commodity chains, it is hoped that consumers will have access to fresher, less processed foods, while producers will realize more profit from their labors and will be motivated to produce foods that are more ethically based and ecologically sustainable for their "close" publics (Robinson \& Hartenfeld, 2007). In addition to the environmental, economic, and social benefits of local food, accessible local food can increase fresh food consumption, making a positive overall contribution to personal health (Ahern, Brown, \& Dukas, 2011).

In view of the benefits of accessible local food, this study evaluated the desire for and consumption of local foods via the local farmers market by low- and mixed-income households in two neighborhood groupings in Bloomington, Indiana, where the main farmers market is managed and facilitated by the municipal parks and recreation department. Our guiding research question was to determine what factors help to explain why some low- and mixed-income households choose to shop at a farmers market, while others do not. Accordingly, our research focus was twofold. First, we sought to explore whether differences existed between the low-income and the mixed-income neighborhood with regard to food values and barriers to accessing food in general. Second, we assessed the variables affecting attendance and food procurement at the farmers market.

\section{Theory}

Farmers markets might best be understood as sites of "agrileisure," a term that encompasses the overlap of agriculture, leisure, and social change (Amsden \& McEntee, 2011). There are many positive outcomes within this framework: farmers capture more revenue in direct-selling schemes ( $\mathrm{La}$ Trobe, 2001); local and regional food systems enhance food security (Hasin, Smith, \& Stieren, 2014); consumers signal their desire for sustainable consumption options (Seyfang, 2006); shoppers attend markets for food purchasing, entertainment, and social networking (Farmer et al., 2011); increased fresh fruit and vegetable consumption has health benefits (Herman, Harrison, Afifi, \& Jenks, 2008); and environmental benefits as well are associated with increased caloric reliance on fresh fruits and vegetables (Godfray et al., 2010).

Critics caution against overly optimistic interpretations of local food effects on communities, however (Hinrichs, 2000; Hinrichs \& 
Kremer, 2002). Especially for low-income populations, local foods can be more expensive than conventionally produced foods found at ordinary grocery stores, may be limited by season, and are more labor-intensive to locate and prepare; they therefore may be perceived as an impractical food option by many potential consumers (Leone et al., 2012). Although the net impact of local foods may be difficult to ascertain, research strongly suggests that increasing geographic and financial access to fresh foods allows people to incorporate these items into their diet more frequently (Herman et al., 2008). Farmers markets, however, have acquired a reputation as exclusive places, geared towards serving the needs of primarily white, female, welleducated, and affluent consumers (Rice, 2015; Wolf, Spittler, \& Ahern, 2005). But a 2012 literature review (Byker, Shanks, Misyak, \& Serrano) of farmers market attendance suggested that markets are slowly diversifying and highlighted the need for more research to understand motivations of not only underrepresented participants but also of all farmers market attendees. Our study is an attempt to shed light on the issues of motivation for attending farmers markets. Specifically we focus on two groups often absent from markets: low- and mixed-income.

Previous studies of low-income and lowincome minority communities have found that farmers market participation results in increased consumption of fresh fruits and vegetables. For example, Pitts et al. (2014) found that more lowincome women in North Carolina who shopped at farmers markets reported eating five or more servings of fruits and vegetables a day (42.1\%) than those who did not shop at farmers markets (24\%). In a similar vein, Evans et al. (2012) reported that farm stands placed in low-income communities increased resident consumption of fresh foods, which helped to combat the perception that goods from farmers markets were too expensive, too far away or inconvenient to access. A study of newly established farmers markets in two low-income neighborhoods in Los Angeles, moreover, found that attendees reported eating more fruits and vegetables as a result of attending the markets (98\% and 97\%, respectively) (Ruelas, Iverson, Kiekel, \& Peters, 2012). Given that engagement in farmers markets seems to support increased fresh food consumption, it is important to understand what contributes to, or hinders, people from utilizing markets in their area.

Evaluation of shopper food values is frequently used in food choice research as a way to understand how people make food consumption decisions (Feldmann \& Hamm, 2015). The priorities people exhibit with regard to their food choices influences which foods they eat, as well as where they purchase them. For example, researchers have used food values to understand what motivates consumers to purchase organic foods even when they are priced higher than conventional alternatives (Hughner, McDonagh, Prothero, Shultz, \& Stanton, 2007). Considering the work of previous food-values scholarship and the fact that local food for purchase at farmers markets often cost more than similar food at supermarkets, we utilized a food-values perspective to explore the motivations and decision to shop at farmers markets.

As food choice is such a complex decision, food values alone do not explain why people make the decisions they do. Access to transportation to and from food outlets is another determinant of food choice. For people without reliable and convenient transportation options, food shopping can be difficult. Geographers have used the concept of "travel burden" to explore the role of distance in food procurement decisions and outcomes (Bader, Purciel, Yousefzadeh, \& Neckerman, 2010). Although a market may be one mile away, that mile may look very different if mobility is complicated by health issues, the addition of young and/or multiple children, the weight of purchases, the scheduling or directness of public transport routes, and the expense of traveling to and from the market. Evaluating the overall difficulty of traveling to food outlets may provide deeper insight than developing inferences based on the Euclidian distance measures frequently employed in food desert research. Consequently, this research seeks to explore how food values, transportation, and location, as well as the demographic variables of income and education, may or may not affect participation in a local farmers market. 


\section{Methods}

\section{Collaborative Research Design}

A collaborative research team including social scientists and local community members directed the research design and instrument development. We utilized Lassiter's (2005) guide to collaborative research in conjunction with collaboration-based research principles outlined by our funding agency, the Clinical and Translational Sciences Initiative. One goal of this project was to foster collaboration between community stakeholders and professional scientists in Bloomington in order for the research to facilitate the development of practical applied solutions to the pressing issue of food security (Fortmann, 2008). This research model allows scientists to engage community stakeholders and to share power, leadership, and responsibility in a manner that makes possible the development of context-specific, or "situated," knowledge (Fortmann, 2008). In this approach, the research scientists and the community partners share the responsibility for development of methods and instruments, and interpretation and dissemination of results.

Community partners included Monroe County United Ministries (MCUM), Bloomington Parks and Recreation (BPR), and the Local Growers' Guild (LGG). MCUM is a local agency that provides emergency services and subsidized childcare to low-income families, for whom the provision of food is a critical service. BPR facilitates the Saturday Bloomington City Farmers' Market (BCFM) and a Tuesday evening market. The LGG is a cooperative of farmers, retailers, and community members dedicated to strengthening the local food system in central and southern Indiana through education, direct support, and market connections.

\section{Research Site}

The city of Bloomington is located in south central Indiana and is home to Indiana University. Four neighborhoods made up our two neighborhood groupings (Figure 1). The first group comprised Crestmont, Reverend Butler, and Walnut Woods, which are housing developments dedicated to government-assisted housing for people living below the poverty line. The second group comprised Highland Village, a mixed-income neighborhood located on the rural-urban fringe of the city and within walking distance of several large grocery stores. Highland Village includes Section 8, rental, and privately owned residences.

\section{Measures to Evaluate Household Income \\ Level and Low-income Designation}

According to federal poverty guidelines, Americans are considered to be living in poverty when their household income is $100 \%$ or less of the federal poverty threshold (Federal Register, 2015). These numbers are generated based on household size and applied uniformly to all states with the exemption of Alaska and Hawaii. A household designated "low-income" is considered to be a household with an income over $100 \%$ but less than $200 \%$ of the federal poverty line. For a family of four, the 2015 poverty line is US $\$ 24,250$, and the low-income line is US $\$ 48,500$. The U.S. Census Bureau reported that as of $2014,58.8$ million people $(15.8 \%$ of the population) lived at or below the poverty line (2015). In Monroe County, where this study was conducted, $24 \%$ of the population was living at or below the poverty line, which is much higher than the Indiana rate of $15.8 \%$ (USDA Economic Research Service [USDA ERS], 2015). For this study, household socioeconomic status was determined using these guidelines.

\section{Research Design, Instruments, Data Collection, and Analysis}

This project used a four-phase mixed-methods sequentially embedded research design (Creswell \& Clark, 2007). The use of sequential design made it possible for each phase to inform the development of the steps that followed, as well as for data collection that allowed both breadth and depth to be derived from the results (Greene, Caracelli, \& Graham, 1989). This paper presents and discusses the results of Phase 1 of the study: a door-to-door survey of two neighborhood groups. ${ }^{1}$ Indiana

\footnotetext{
${ }^{1}$ The additional phases of the research included a survey of farmers concerning interest in aggregating food for redistribution, in-depth interviews with social service agencies working on community food security, and a survey of SNAP vs. nonSNAP consumers at farmers markets.
} 
University's human subjects Internal Review Board approved this study (Protocol \# 1409219588). All participants were given a US $\$ 10$ gift certificate to the Bloomington Community Farmers' Market to incentivize their participation.

Based on the primary purpose of understanding food access issues and interest/participation in farmers markets, the team developed a six-page, 27-question instrument (Appendix A). Questions focused on household characteristics, demographics, food procurement behavior and experiences, historical experiences with local food operations, attendance at the BCFM, food redistribution/ reciprocity, government social service benefits (SNAP, WIC, etc.), food consumption behavior, food values (nutrition, freshness, quality, convenience, chemical-free status, price, origin), use of food pantries, and Internet usage. (We used

\section{Figure 1. Map of Bloomington, Indiana, Research Sites and Location of Bloomington Community}

Farmers' Market

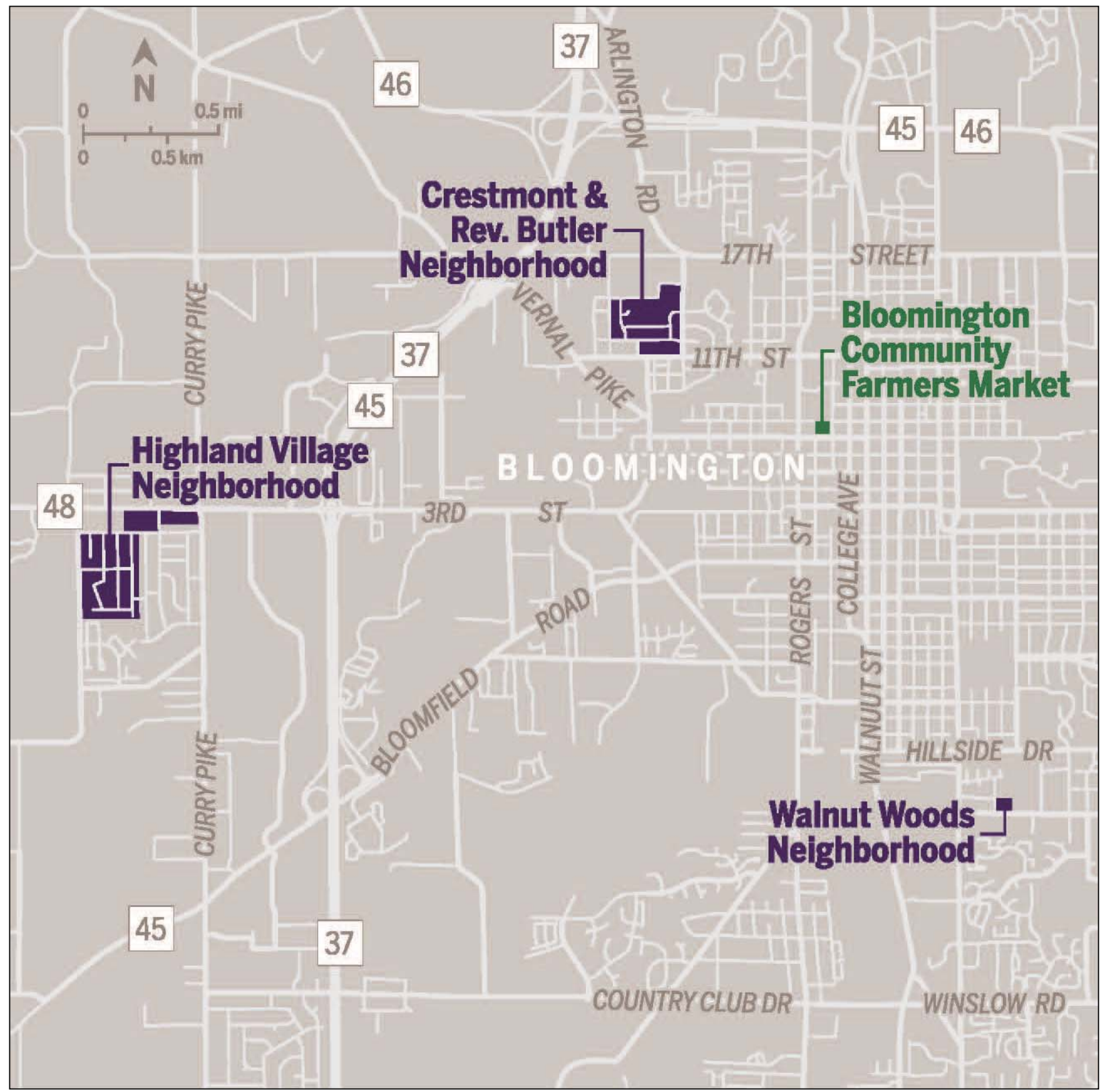


"Chemical Free" to indicate foods produced without the use of pesticides or herbicides. "Nutrition," or how nutritious a food is, was used in place of other researchers' "Health" metric. "Freshness/ Quality" and "Locally Produced" were included to test if farmers market customers would rate these values more highly than those who do not participate.) Researchers piloted the questionnaire on two occasions in late November at the MCUM office.

Door-to-door household interviews were conducted between December 2014 and March 2015. In research teams of two, we approached 197 households and invited them to participate in the study. One researcher filled responses directly into iSurvey on an iPad; the other took down responses on paper along with any additional comments made by the respondent. Additional comments were entered into a Microsoft Word document for later analysis. In the interest of keeping survey time to a minimum, any information that the iPad operator missed was backfilled into the survey file.

This study used a six-item food-value scale to evaluate how household food values align with participation in a local farmers market. Earlier surveys engaged a variety of factors to evaluate the motivation to purchase foods considered ethically produced (Lindeman \& Väänänen, 2000; Lockie, Lyons, Lawrence, \& Mummery, 2002). Frequently used metrics include price and convenience (how easy the item is to prepare or consume). Our hypothesis is that consumers for whom price and convenience are high priorities will be less likely to attend farmers markets.

We performed several statistical analyses on the survey data. We began by calculating descriptive statistics on demographic variables for the sample as a whole and between the two groups. We tested between-group scores using the chisquared test. Next, we compared the food value (see Table 2) scores of the two groups using an analysis of variance (ANOVA). We also conducted a Kaiser-Meyer-Olkin (KMO) measure of sampling adequacy, Bartlett's test for equality of variances, and principal-component analyses on the six items used to account for food value (chemical-free status, convenience, freshness/quality, local origin, nutrition, price). The results of these analyses indicated that data for each item were sufficiently correlated for principle-component analysis (PCA) to be useful in reducing dimensionality. We conducted PCA on values for all six items. Bartlett's test confirmed the significance of the first PCA axis, then calculating eigenvalues of variance and scree plotting determined how many additional axes to interpret. We report partial correlations for the two PCA axes and the communality values, which showed the proportion of variation in a category that was retained in the mathematical solution (in this case, the two PCA axes). Finally, we used binary logistic regression analyses to understand what variables predict participation in the farmers market among low- to middle-income individuals. Finally, we used correlation analysis to explore the relationship between education and income, as they tend to vary together.

\section{Results}

\section{Response Results, Demographics, and Personal and Behavior Characteristics}

We solicited data from 197 potential participants, of whom 102 completed the questionnaire (51.8\% response rate). Based on the neighborhood classification, a categorical variable was created to partition participants into the two groups. Thus, 48 participants (46.6\%) made up the mixed-income neighborhood group and 54 participants (53.4\%) made up the low-income neighborhood grouping. The income composition based on the 2015 poverty guidelines for our two groups consisted of $61.8 \%$ poor and $38.1 \%$ low income for the lowincome neighborhood group, and $29.1 \%$ poor, $25.0 \%$ low-income, and $45.8 \%$ middle-income or higher for the mixed income group. (See Table 1 for further details on demographic data.)

We queried participants about their ease or difficulty getting to the grocery store, providing a 1-4 style scale for possible responses $(1=$ very difficult; $2=$ difficult; $3=$ easy; $4=$ very easy). Respondents from the low-income neighborhoods reported a mean score of 1.49 , while mixed-income neighborhood respondents had a mean score of 1.87. An ANOVA comparing the scores resulted in a statistical difference at $\mathrm{p}<0.05$. Averaging the distance of the three closest grocery stores to 
produce a general mean distance-to- grocery-score, we found that the low-income group lived a mean distance of .76 miles (1.22 kilometers) from a store and the mixed-income group lived .71 miles $(1.14$ $\mathrm{km}$ ) away. The distance from the center of the lowincome neighborhood to the Bloomington Community Farmers' Market is 1.14 miles $(1.83 \mathrm{~km})$, however, while the distance to the farmers market

Table 1. Demographic Results and Comparison Between Neighborhood Groups

\begin{tabular}{|c|c|c|c|}
\hline Variables & Overall & $\begin{array}{l}\text { Mixed Income } \\
\text { Neighborhood }\end{array}$ & $\begin{array}{c}\text { Low Income } \\
\text { Neighborhood }\end{array}$ \\
\hline Gender & $42.6 \%$ & $51.1 \%$ & $35.2 \%$ \\
\hline \multicolumn{4}{|l|}{ Male } \\
\hline Female & $57.4 \%$ & $48.9 \%$ & $64.8 \%$ \\
\hline Mean Age & 48.50 & 53.02 & 44.56 \\
\hline Household Size & 2.50 & 2.31 & 2.65 \\
\hline$\%$ with Children & $42.7 \%$ & $33.3 \%$ & $51.0 \%$ \\
\hline \multicolumn{4}{|l|}{ Educational Attainment* } \\
\hline Did not finish HS & $20.9 \%$ & $6.4 \%$ & $37.0 \%$ \\
\hline HS / GED & $36.6 \%$ & $30.3 \%$ & $37.0 \%$ \\
\hline Some college & $19.8 \%$ & $25.5 \%$ & $14.8 \%$ \\
\hline Associate's or Tech. Degree & $5.9 \%$ & $8.5 \%$ & $3.7 \%$ \\
\hline B.S. / B.A. & $8.9 \%$ & $14.9 \%$ & $2.7 \%$ \\
\hline Master's Degree & $5.9 \%$ & $8.5 \%$ & $3.7 \%$ \\
\hline Professional Degree & $1.0 \%$ & $2.1 \%$ & $0 \%$ \\
\hline \multicolumn{4}{|l|}{ Ethnicity } \\
\hline Black & $12.9 \%$ & $12.8 \%$ & $13.0 \%$ \\
\hline American Indian or Alaska Native & $1.0 \%$ & $0 \%$ & $1.9 \%$ \\
\hline Asian & $2.0 \%$ & $2.1 \%$ & $1.9 \%$ \\
\hline Hispanic & $4.0 \%$ & $6.4 \%$ & $1.9 \%$ \\
\hline White & $78.2 \%$ & $74.5 \%$ & $81.5 \%$ \\
\hline Other & $2.0 \%$ & $4.3 \%$ & $1.8 \%$ \\
\hline \multicolumn{4}{|l|}{ Household Income Level (US\$)* } \\
\hline$\$ 0$ & $7.1 \%$ & $2.3 \%$ & $11.1 \%$ \\
\hline$\$ 1-\$ 11,670$ & $39.8 \%$ & $6.8 \%$ & $66.7 \%$ \\
\hline$\$ 11,670-\$ 19,789$ & $19.4 \%$ & $20.4 \%$ & $18.6 \%$ \\
\hline$\$ 19,789-\$ 27,909$ & $9.2 \%$ & $18.2 \%$ & $1.9 \%$ \\
\hline$\$ 27,910-\$ 36,029$ & $6.1 \%$ & $11.4 \%$ & $1.9 \%$ \\
\hline$\$ 36,030-\$ 45,039$ & $7.1 \%$ & $15.9 \%$ & $0 \%$ \\
\hline$\$ 45,040+$ & $11.3 \%$ & $24.2 \%$ & $0 \%$ \\
\hline \multicolumn{4}{|l|}{ Poverty Status*** Classification } \\
\hline Poor & $46.6 \%$ & $29.1 \%$ & $61.8 \%$ \\
\hline Low Income & $32.0 \%$ & $25.0 \%$ & $38.1 \%$ \\
\hline Middle + Income & $21.4 \%$ & $45.8 \%$ & $0 \%$ \\
\hline
\end{tabular}

$* p<.05 ; * * p<.01 ; * * * p<.001$ from the mixed-income neighborhood is 3.13 miles $(5.04 \mathrm{~km})$. Among the households classified as poor or low-income, $48.75 \%$ had children younger than 18 in the household. Chi-squared analysis was performed on each of the variables in Table 1, comparing the two groups. Not surprisingly, significant differences were found between the two neighborhood groups for educational attainment

$(p<0.05)$ and income

$(p<0.001)$. Income and educational attainment levels were both higher in the mixed-income neighborhood group at the .05 level. Collectively, $37 \%$ of the individuals living in the low-income neighborhood grouping did not finish high school, while only $6.4 \%$ of those in the mixed-income neighborhood had not finished high school.

\section{Motive-V alues Affecting Food Purchases}

Overall, participants indicated that they are most persuaded by the freshness and quality of food when making purchasing decisions, followed by price, nutrition, chemical-free status, convenience in preparation, and local production (Table 2). Both groups scored freshness and quality the highest of the six variables. An ANOVA was used to compare data between the two neighborhoods. A significant difference was detected between the scores of the neighborhoods with regard to chemical-free status: the mixed-income neighborhood showed a stronger interest in chemical-free food. We also tested the difference in the six values based on whether an individual attended the farmers market. 
Table 2. Comparison of Food Values

(1-5 Likert scale: $1=$ not a priority, 2=low priority, 3=neutral, 4=moderate priority, 5=high priority)

\begin{tabular}{lccccc}
\hline \multicolumn{1}{c}{ Prompt from Questionnaire } & Overall Scores & $\begin{array}{c}\text { Mixed Income } \\
\text { Neighborhood }\end{array}$ & $\begin{array}{c}\text { Low Income } \\
\text { Neighborhood }\end{array}$ & $\begin{array}{c}\text { Non-FM } \\
\text { Farticipant }\end{array}$ \\
Chemical-Free Status & 3.54 & $3.98^{* *}$ & $3.15^{* *}$ & 3.69 & 3.40 \\
Convenience in Preparation & 3.53 & 3.71 & 3.37 & 3.33 & 3.72 \\
Freshness/Quality & 4.61 & 4.69 & 4.54 & $4.78^{*}$ & $4.45^{*}$ \\
Locally Produced & 3.33 & 3.54 & 3.15 & 3.51 & 3.17 \\
Nutrition & 4.16 & 4.29 & 4.04 & 4.20 & 4.11 \\
Price & 4.27 & 4.19 & 4.35 & 4.21 & 4.32 \\
\hline
\end{tabular}

$* p<.05 ; * * p<.01 ; * * * p<.001$

While farmers market participants had numerically higher scores on the desire for chemical-free food, locally produced food, nutritious foods, and freshness/quality of food variables, they also had lower scores than non-participants when it came to valuing convenience in preparation and the price of food. That said, only the freshness/quality value was significantly different between the two groups. A PCA was conducted on the six items with Varimax rotation. The Kaiser-Mayer-Olkin (KMO) measure verified the sampling adequacy for the analysis $(\mathrm{KMO}=.641)$, which is adequate according to Hutcheson and Sofroniou (1999), and all loading values for individual items were near or above .500, which is acceptable according to Field (2013). We ran initial analyses to obtain eigenvalues for each factor in the data. Two factors had eigenvalues over Kaiser's criterion of 1.0, and in combination explained $52.073 \%$ of the variance. Table 3 shows the component loading after rotation. The items that cluster on the same component suggest that component 1 represents healthy local food (31.76\% of variance), and component 2 represents economical and easy to prepare food $(20.31 \%$ of variance).

\section{Attending the Farmers Market} Among the 102 study participants, $48.5 \%$ indicated that they attend the Bloomington Community Farmers' Market at least four times a year. In the mixed-income neighborhood, $47.9 \%$ attend the farmers market more than four times a year. Similarly,
$50 \%$ of the individuals living in the low-income neighborhood attend the farmers market with the same relative frequency. We asked non-attendees, in an open-ended format, why they do not attend the farmers market. The most common reason given was "inconvenience" (11.8\%). Individuals elaborated that the parking was inconvenient, shopping with kids was hard, or that they would then need to go to multiple establishments to do all of their food shopping. Most (93.2\%) participants knew where the market was located, while 3.9\% stated that the prices at the market were too high and $2.9 \%$ suggested the hours of operation deterred their attendance. Using chi-squared test, we tested market attendance based on federal poverty guideline classifications and found no statistical differences based on being poor, low-income, or middle-income; however, when grouping poor and low-income together against the middle-income group, a statistical difference existed at .049 using a one-way ANOVA.

A stepwise logistic regression used to evaluate the differences between market attendees and nonattendees $(0=$ does not attend the farmers market; $1=$ attends the farmers market) predicted the
Table 3. Principle-component Analysis (PCA) Results of Six Variables Affecting Food Purchasing Choices

\begin{tabular}{lcc}
\hline \multicolumn{1}{c}{ Prompt from Questionnaire } & Healthy Local Food & Cheap and Easy Food \\
\hline Chemical-Free Status &. $\mathbf{7 4 2}$ & .086 \\
Convenience in Preparation & -.010 &. $\mathbf{7 4 8}$ \\
Freshness/Quality & .490 & -.495 \\
Locally Produced & .739 & -.054 \\
Nutrition & .656 & .351 \\
Price & .300 & $\mathbf{. 5 7 4}$ \\
\hline
\end{tabular}


outcome accurately $69.8 \%$ of the time (Table 4 ). The model predicted whether individuals would attend the farmers market correctly $71.8 \%$ of the time, and with $68.4 \%$ accuracy whether individuals would not attend. Covariates in the model included the neighborhood grouping, the six value items listed in Table 2, the difficulty level in traveling to and from the grocery store, and income level. The model was significant $(p=.009)$, fit the data well (Hosmer and Lemeshow Goodness of Fit Test $p=0.791$ ), and retained two significant items: freshness/quality and difficulty in getting to the grocery store. As the value for freshness/quality increased on the Likert scale, the participants' likelihood of shopping at the farmers market increased by $172.6 \%$. Additionally, as getting to the grocery store became easier for an individual (according to movement up on the Likert scale), the likelihood of someone attending the market increased by $97.3 \%$. Notably, household income level and ease of getting to the grocery store were positively correlated $(\mathrm{r}=0.387, n=98, p=0.000)$ across all respondents.

\section{Discussion}

We sought to better understand the use of farmers markets by low- and mixed-income households in two neighborhood groupings in a city with one primary farmers market. Thus, this research highlights factors affecting low- and middle-income

Table 4. Summary Statistics of the Binary Logistic Regression Model in Which Farmers Market Participation Was Regressed on 10 Independent Variables

Significant variables and model statistics are listed.

\begin{tabular}{lc}
\hline & $\begin{array}{c}\text { Model 1 } \\
\text { (Step 2) }\end{array}$ \\
\hline Model Sign. & .009 \\
Hosmer Lemeshow & .791 \\
Chi-squared & 6.748 \\
-2 Log Likelihood & 113.639 \\
Nagelkerke & .208 \\
Percentage Accuracy & $68.4 \%$ \\
\hline \multicolumn{1}{c}{ Variables } & $B($ S.E.; Exp(B) \\
\hline Q. 31.3- Freshness/Quality & $1.003(.437 ; 2.726)^{*}$ \\
Difficulty in getting to the grocery store & $0.679(.248 ; 1.973)^{* *}$ \\
\hline Constant & $-7.011(2.236 ; .001)^{* *}$ \\
\hline
\end{tabular}

S.E. Standard Error; ${ }^{*} p<.05 ; * * p<.01 ; * * * p<.001$ populations' participation in a local farmers market. Though exploratory in nature, it is clear that while income and educational attainment differences existed between the neighborhood groups, the major factors contributing to their participation are the value of fresh/quality food and the ease/ difficulty of transporting themselves to acquire food. The PCA results indicated that participant food values clustered according to two main themes: healthy local food, and cheap and easy to prepare food. This result is consistent with discussions in the literature that equate healthy and nutritional with local (Zepeda \& Li, 2006), in large part due to product freshness. Lamine (2005), Sage (2003), and Smithers, Lamarche, and Joseph (2008) all point to this value as a key motivational attribute provisioned through local food. The study by Smithers et al. (2008) of Ontario farmers markets found freshness key in market consumer responses, while according to market vendor understanding of consumer demands, freshness was paramount.

Also critical to evaluating attendance at markets and in the procurement of food in general is ease or difficulty in getting to the market or grocery store. As our results show, level of difficulty in getting to the grocery store-representing the concept of "transportation barrier" - significantly predicted participation and non-participation among respondents. A statewide Indiana study found farmers market location in relation to residence was also found to be determinative of participation. Farmer, Chancellor, Robinson, West, and Weddell (2014) found that those who do participate as consumers at farmers markets generally lived about half the distance to a farmers market as those who do not attend. Markowitz (2010) found a similar result, with farmers market consumers at Louisville, KY farmers markets living closer to markets than nonattendees.

As indicated by the high correlation between ease of getting to a grocery and income, as well as the ANOVA result comparing 
low-income with middle-income consumers, our findings support previous research that indicates farmers market visitors tend to be more affluent than non-visitors (Macais, 2008), an important variable identified throughout critiques of the local food movement (Guthman, 2008; Hinrichs, 2000). Reliable, affordable, and convenient transportation options can help to close this distance and facilitate the use of markets by community members who live further from market locations. Parallel to our results, transportation is often found positively correlated to income as a constraint in a variety of contexts (Garasky, Fletcher, \& Jensen, 2006; Park et al., 2009). This underscores the importance of minimizing transportation barriers to enhance accessibility to local foods. An alternative to providing better public transport options would be to establish markets in low-income neighborhoods that could reflect the culture of the community as opposed to forcing diffusion into the market's dominant culture. Future research should further investigate the overall transportation dynamic of poor and low-income residents and farmers market attendance, as it is not a given that simply providing transportation will remedy the issue since a variety of other variables (such as work schedules, children in the household, adults in the household, etc.) may affect when and how transportation might be used.

Additionally, this study has a number of limitations that should be addressed and remedied in future research. Our six-factor value scale should be refined to include multiple items for each factor to allow for more precise measurement of participant values. This would also allow for the calculation of reliability scores in order to enhance the generalizability of research using the scale. Having a larger sample size would enable the use of more rigorous statistical measures that would also enhance generalizability of conclusions. An effort to expand sample neighborhood diversity would allow a comparison of individuals across a broader economic and geographic spectrum. Our use of a gift certificate to the farmers market, while well suited for those that have an interest in the market, likely created bias with those respondents who were enticed, and may have dissuaded others from participating. Future research should use a more general incentive, such as a gift card from a major credit card company, a cash incentive, or a gift certificate to a local grocery store in order to minimize selection bias and increase participation.

\section{Conclusion}

Research on farmers market participants has made evident several motivations for attending: to participate and purchase within a local food system, access quality foods in season, demonstrate concern for the environment, and obtain information about growing practices (Cone \& Myhre, 2000; Cox et al., 2008; Delind, 2006; Hinrichs, 2000). Few studies exist that compare market participants with nonparticipants (Farmer et al., 2014), however, and even fewer exist that do so from outside the farmers market setting. Our results suggest that an individual's preference for quality/fresh food was the most significant determinant among six values tested to explain why an individual does or does not attend the farmers market. For those in our sample that did not attend, price and convenience were the two most important factors in their food shopping choices. This six-item value scale could be of utility to other community food-system scholars and professionals seeking to evaluate factors that explain food choice.

This study has three primary professional implications for those working on farmers market and local food system development. First, our results indicate the importance of ongoing community health education efforts. Preference for fresh/quality food is one of two decisive factors for those attending farmers markets, and community education can help to promote the availability of fresh and high-quality local foods at farmers markets. Our research indicates that individuals attending the market value food freshness and quality most highly in their shopping decisions. In light of this, we recommend that these be specifically highlighted in city-sponsored messages and marketing materials in order to increase market participation. Second, situating markets in close proximity to public transportation hubs or within low-income neighborhoods would help to facilitate market participation for those without personal transport options. Atlanta has recently put a farmers market in the West End transit station, a 
neighborhood classified as a food desert, as a means of enhancing the food security of the area's residents, which highlights proximity as a vital component to farmers market participation (Farmer et al., 2011). Finally, transportation issues may be overcome by taking the market directly to the people, via a mobile market. Mobile markets are developing throughout the country through the joint efforts of grower groups, local nonprofits positioned in and with the communities, governmental agencies, and for-profit health organizations, which may be a more realistic way to facilitate access to fresh foods for those in need (SatinHernandez \& Robinson, 2015). In their current iteration, farmers markets are a form of agriliesure primarily for those who are able to attend and can afford to shop once they are there. In order to understand how local foods may be made more accessible to all, we must first address what factors make this purported leisure experience actually an "agriburden" for many consumers.

\section{Acknowledgements}

We thank the participants who completed the survey; Indiana University's School of Public HealthBloomington; and Ms. Bridget Masur, Ms. Natalie Woodcock, Mr. Eric Knackmuhs, and Mr. Brian Croft for their assistance in data collection. We also thank the anonymous reviewers for their suggestions and comments throughout the review process.

\section{References}

Ahern, M., Brown, C., \& Dukas, S. (2011). A national study of the association between food environments and county-level health outcomes. The Journal of Rural Health, 27(4), 367-379. http://dx.doi.org/ 10.1111/j.1748-0361.2011.00378.x

Amsden, B., \& McEntee, J. (2011). Agrileisure: Reimagining the relationship between agriculture, leisure, and social change. Leisure/Loisir, 35(1), 37-48. http://dx.doi.org/10.1080/ $\underline{14927713.2011 .549194}$

Bader, M. D. M., Purciel, M., Yousefzadeh, P., \& Neckerman, K. M. (2010). Disparities in neighborhood food environments: Implications of measurement strategies. Economic Geography, 86(4), 409-430. http://dx.doi.org/10.1111/j.19448287.2010.01084.x
Byker, C., Shanks, J., Misyak, S., \& Serrano, E. (2012). Characterizing farmers' market shoppers: A literature review. Journal of Hunger and Environmental Nutrition, 7(1), 38-52. http://dx.doi.org/10.1080/19320248.2012.650074

Cone, C., \& Myhre, A. (2000). Community-supported agriculture: A sustainable alternative to industrial agriculture? Human Organization, 59(2), 187-197. http://dx.doi.org/10.17730/humo.59.2.715203t206 g2j153

Cox, R., Holloway, L., Venn, L., Dowler, L., Hein, J. R., Kneafsey, M., \& Toumainen, H. (2008). Common ground? Motivations for participation in a community-supported agriculture scheme. Local Environment, 13(3), 203-218. http://dx.doi.org/10.1080/13549830701669153

Creswell, J. W., \& Plano-Clark, V. L. (2007). Designing and conducting mixed methods research. Thousand Oaks, California: Sage.

Dahlberg, K. A. (1993). Regenerative food systems: Broadening the scope and agenda of sustainability. In P. Allen (Ed.), Food for the future: Conditions and contradictions of sustainability (pp. 75-102). New York: Wiley.

DeLind, L. (2006). Of bodies, place, and culture: Resituating local food. Agricultural and Environmental Ethics, 19(2), 121-146. http://dx.doi.org/10.1007/s10806-005-1803-z

Evans, A. E., Jennings, R., Smiley, A. W., Medina, J. L., Sharma, S. V, Rutledge, R., ... Hoelscher, D. M. (2012). Introduction of farm stands in low-income communities increases fruit and vegetable among community residents. Health \& Place, 18(5), 11371143. http://dx.doi.org/10.1016/j.healthplace. 2012.04.007

Farmer, J. R., Chancellor, C., Gooding, A., Shubowitz, D., \& Bryant, A. (2011). A tale of four farmers markets: Recreation and leisure as a catalyst for sustainability. Journal of Park and Recreation Administration, 29(3), 11-23. http://js.sagamore pub.com/jpra/article/view/2252

Farmer, J. R., Chancellor, C., Robinson, J. M., West, S., \& Weddell, M. (2014). Agrileisure: Farmers' markets, CSAs, and the privilege in eating local. Journal of Leisure Research, 46(3), 313-328. http://js.sagamorepub.com/jlr/article/view/5186 
Federal Register. (2015). 2015 poverty guidelines. Washington, D.C.: Assistant Secretary for Planning and Evaluation, U. S. Department of Health and Human Services. Retrieved from http://aspe.hhs.gov/poverty/15poverty.cfm

Feldmann, C., \& Hamm, U. (2015). Consumers' perceptions and preferences for local food: A review. Food Quality and Preference, 40(A), 152-164. http://dx.doi.org/10.1016/j.foodqual.2014.09.014

Field, A. (2013). Discovering statistics using IBM SPSS statistics. (4 ${ }^{\text {th }}$ ed.). Thousand Oaks, California: Sage.

Fortmann, L. (2008). Introduction: Doing science together. In L. Fortmann (Ed.), Participatory research in conservation and rural livelihoods: Doing science together (pp. 1-17). Hoboken, New Jersey: John WileyBlackwell.

Garasky, S., Fletcher, C. N., \& Jensen, H. H. (2006), Transiting to work: The role of private transportation for low-income households. Journal of Consumer Affairs, 40(1), 64-89. http://10.1111/j.1745$\underline{6606.2006 .00046 . x}$

Godfray, H. C. J., Beddington, J. R., Crute, I. R., Haddad, L., Lawrence, D., Muir, J. F., ... Toulmin, C. (2010). Food security: The challenge of feeding 9 billion people. Science, 327(5967), 812-818. http://dx.doi.org/10.1126/science.1185383

Greene, J., Caracelli, V., \& Graham, W. (1989). Toward a conceptual framework for mixed method evaluation designs. Educational Evaluation and Policy Analysis, 11(3), 255-274. http://dx.doi.org/10.3102/01623737011003255

Guthman, J. (2008). "If they only knew": Color blindness and universalism in California alternative food institutions. The Professional Geographer, 60(3), 387-397.

http://dx.doi.org/10.1080/00330120802013679

Hasin, A., Smith, S., \& Stieren, P. (2014). Illinois farmers markets using EBT: Impacts on SNAP redemption and market sales. Journal of Agriculture, Food Systems, and Community Development, 5(1), 179-188. http://dx.doi.org/10.5304/jafscd.2014.051.015

Herman, D. R., Harrison, G. G., Afifi, A. A., \& Jenks, E. (2008). Effect of a targeted subsidy on intake of fruits and vegetables among low-income women in the Special Supplemental Nutrition Program for Women, Infants, and Children. American Journal of Public Health, 98(1), 98-105. http://dx.doi.org/10.2105/AJPH.2005.079418
Hinrichs, C. C. (2000). Embeddedness and local food systems: Notes on two types of direct agricultural market. Journal of Rural Studies, 16(3), 295-303. http://dx.doi.org/10.1016/S0743-0167(99)00063-7

Hinrichs, C. C. (2003). The practice and politics of food system localization. Journal of Rural Studies, 19(1), 33-45. http://dx.doi.org/10.1016/S07430167(02)00040-2

Hinrichs, C. C., \& Kremer, K.S., (2002). Social inclusion in a Midwest local food system project. Journal of

Poverty, 6(1), 65-90. http://dx.doi.org/10.1300/J134v06n01 04

Hughner, R. S., McDonagh, P., Prothero, A., Shultz, C. J., \& Stanton, J. (2007). Who are organic food consumers? A compilation and review of why people purchase organic food. Journal of Consumer Behaviour, 6(2-3), 94-110. http://dx.doi.org/10.1002/cb.210

Hutcheson, G. D., \& Soroniou, N. (1999). The multivariate social scientist: Introductory statistics using generalized linear models. London \& Thousand Oaks, California: Sage.

Lamine, C. (2005). Settling shared uncertainties: Local partnerships between producers and consumers. Sociologia Ruralis, 45(4), 324-345. http://dx.doi.org/ 10.1111/i.1467-9523.2005.00308.x

Lassiter, L. E. (2005). The Chicago guide to collaborative ethnography. Chicago: University of Chicago Press.

La Trobe, H. (2001). Farmers' markets: Consuming local rural produce. International Journal of Consumer Studies, 25(3), 181-192. http://dx.doi.org/10.1046/j.14706431.2001.00171.x

Leone, L. A., Beth, D., Ickes, S. B., MacGuire, K., Nelson, E., Smith, R. A., ... Ammerman, A. S. (2012). Attitudes toward fruit and vegetable consumption and farmers' market usage among low-income North Carolinians. Journal of Hunger \& Environmental Nutrition, 7(1), 64-76. http://dx.doi.org/10.1080/19320248.2012.651386

Lindeman, M., \& Väänänen, M. (2000). Measurement of ethical food choice motives. Appetite, 34(1), 55-59. http://dx.doi.org/10.1006/appe.1999.0293

Lockie, S., Lyons, K., Lawrence, G., \& Mummery, K. (2002). Eating "Green": Motivations behind organic food consumption in Australia. Sociologia Ruralis, 42(1), 23-40. http://dx.doi.org/10.1111/1467-9523.00200 
Lyson, T. A. (2004) Civic agriculture: Reconnecting farm, food and community. Lebanon, New Hampshire: Tufts University Press-University Press of New England.

Macais, T. (2008). Working toward a just, equitable, and local food system: The social impact of communitybased agriculture. Social Science Quarterly, 89(5), 1086-1101. http://dx.doi.org/10.1111/j.15406237.2008.00566.x

Markowitz, L. (2010). Expanding access and alternatives: Building farmers' markets in low-income communities. Food and Foodways, 18(1-2), 66-80. http://dx.doi.org/10.1080/07409711003708512

Martinez, S., Hand, M., Da Pra, M., Pollack, S., Ralston, K., Smith, T., ...Newman, C. (2010). Local food systems: Concepts, impacts, and issues. Washington, DC: U. S. Department of Agriculture, Economic Research Service. (ERR 97). Retrieved from http://www.ers.usda.gov/media/122868/ err97 1 .pdf

Park, N. S., Roff, L. L., Sun, F., Parker, M. W., Klemmack, D. L., Sawyer, P., \& Allman, R. M. (2009). Transportation difficulty of black and white rural older adults. Journal of Applied Gerontology, 29(1), 70-88. http://dx.doi.org/10.1177/0733464809335597

Pitts, S. B. J., Gustafson, A., Wu, Q., Mayo, M. L., Ward, R. K., McGuirt, J. T., \& Keyserling, T. C. (2014). Farmers' market use is associated with fruit and vegetable consumption in diverse southern rural communities. Nutrition Journal, 13(1), 1-11. http://dx.doi.org/10.1186/1475-2891-13-1

Rice, J. S. (2015). Privilege and exclusion at the farmers market: findings from a survey of shoppers. Agriculture and Human V alues, 32(1), 21-29. http://dx.doi.org/10.1007/s10460-014-9513-7

Robinson, J. M., \& Hartenfeld, J. A. (2007). The farmers' market book: Growing food, cultivating community. Bloomington: Indiana University Press.

Ruelas, V., Iverson, E., Kiekel, P., \& Peters, A. (2012). The role of farmers' markets in two low income, urban communities. Journal of Community Health, 37(3), 554-562. http://dx.doi.org/10.1007/s10900011-9479-y

Sage, C. (2003). Social embeddedness and the relations of regard: Alternative 'good food' networks in south-west Ireland. Journal of Rural Studies, 19(1), 47-60. http://dx.doi.org/10.1016/S07430167(02)00044-X
Satin-Hernandez, E., \& Robinson, L. (2015). A community engagement case study of the Somerville Mobile Farmers' Market. Journal of Agriculture, Food Systems, and Community Development, 5(4), 95-98. http://dx.doi.org/10.5304/jafscd.2015.054.015

Seyfang, G. (2006). Ecological citizenship and sustainable consumption: Examining local organic food networks. Journal of Rural Studies, 22(4), 383-395. http://dx.doi.org/10.1016/j.jrurstud.2006.01.003

Smithers, J., Lamarche, J., \& Joseph, A. E. (2008). Unpacking the terms of engagement with local food at the farmers' market: Insights from Ontario. Journal of Rural Studies, 24(3), 337-350. http://dx.doi.org/10.1016/j.jrurstud.2007.12.009

U.S. Census Bureau. (2015). QuickFacts United States: Income and poverty. Washington, D.C.: USCB, U. S. Department of Commerce. Retrieved from http://www.census.gov/quickfacts/table/PST0452 $\underline{14 / 18105,00}$

U.S. Department of Agriculture, Agricultural Marketing Service [USDA AMS]. (2016). Farmers markets and direct-to-consumer marketing. Washington, DC: Author. Retrieved from https://www.ams.usda.gov/ services/local-regional/farmers-markets-and-directconsumer-marketing

U.S. Department of Agriculture, Economic Research Service [USDA ERS]. (2015). County-level data sets: Percent of total population in poverty, 2014. Washington, D.C.: Author. Retrieved from http://www.ers. usda.gov/data-products/county-level-datasets/poverty.aspx

Wolf, M. M., Spittler, A., \& Ahern, J. (2005). A profile of farmers' market consumers and the perceived advantages of produce sold at farmers' markets. Journal of Food Distribution Research, 36(1), 192-201. http://purl.umn.edu/26768

Zepeda, L., \& Li, J. (2006). Who buys local food? Journal of Food Distribution Research, 37(3), 1-11. http://purl.umn.edu/7064 